\title{
Decision Support System for Selection of Achieving Students Using the Multi Attribute Rating Technique Method
}

\author{
Farid Wahyudi ${ }^{*}$ Listanto Tri Utomo ${ }^{2}$ \\ 1. Information System Study Program, Faculty of Science and Technology, Raden Rahmat Islamic \\ University of Malang, Indonesia \\ 2. Informatics Engineering Study Program, Faculty of Science and Technology, Raden Rahmat Islamic \\ University of Malang, Indonesia \\ * E-mail of the corresponding author: faridstifler@gmail.com
}

\begin{abstract}
The background of this research is the process of selecting students in SMA Negeri 1 Sumberpucung so far is still not objective because it only looks at the best report card grades without any other process. That causes the inappropriate selection of high achieving students in SMA Negeri 1 Sumberpucung because the student is not only assessed in terms of report cards but also needs to consider other factors. So the selected students can represent the school at a higher level, namely the district and provincial levels. The purpose of this study is to build a decision support system to help selectors make the selection of high achieving students in SMA Negeri 1 Sumberpucung and assist in making decisions in the selection process of high achieving students using the Simple Multi Attribute Rating Technique (SMART) method. The stages of the research method used the waterfall software development method. In the first stage, an analysis of input and output needs is carried out, the second stage is by designing a decision support system using the SMART method, the third stage is customizing the decision support system, the fourth stage of program testing and the final stage of program implementation. The Decision support system is built based on the web and uses a MySQL database. From this research, it is expected to be able to produce an application or decision support system software.
\end{abstract}

Keywords: Decision Support System; Student Achievement Selection; Simple Multi Attribute Rating Technique (SMART)

DOI: $10.7176 / \mathrm{IKM} / 10-5-06$

Publication date:August $31^{\text {st }} 2020$

\section{Introduction}

Being an outstanding student is the dream of every school-age child, stands out among the other students. The achievement obtained is certainly based on an ability to the knowledge possessed by each student, so this achievement will even be very helpful in obtaining a good life in the future. Every educational institution, especially at senior high school, always has a vision and mission-oriented to smart graduates, excel in achievement, broad-minded, and realize international grade ratings such as in SMA Negeri 1 Sumberpucung. To realize this desire each school needs to evaluate, further improve its services in teaching techniques, assessment, quality assurance to make schools competitive, quality, and achievement. Thus, by the problems that have previously existed from the school, sometimes teacher is still have difficulty to determine the prospective students who will be included in the learning Olympics at the High School level each year.

The data in SMA Negeri 1 Sumberpucung, especially the assessment data about students and other data in this school are mostly still manually. So the data is still vulnerable to being lost and the selection system for high achieving students is still subjective by looking at report card grades. Therefore, there is still need something to be developed to compete with other schools of equal level. Based on the description above, it can be designed a system to assist teachers in determining the decisions of high achieving students, where the results can also be taken into consideration by teachers to determine students who will be included when the school gets an invitation to study each year, and also help the school to determine prospective students who deserve a scholarship. These problems are the basis of researchers to develop decision support systems using the Simple Multi Attribute Rating Technique (SMART) method in SMA Negeri 1 Sumberpucung. Implementing a decision support system using the SMART method will help the selection team in the selection of outstanding students. 


\section{Literature Review}

\subsection{The System}

A unity of procedures or components that are interrelated with one another, work together by the rules applied to form a common goal, wherein a system if there is only one part that is not working or damaged, then a goal can be the result of errors or the output. The system is a collection of interrelated elements that are responsible for processing inputs so that they produce. (Kusrini, 2007: 4)

\subsection{Decision Support System}

Decision Support System (DSS) is broadly defined as a computer-based system that helps people to use computer communications, data, documents, knowledge, and models to overcome problems and make decisions. DSS is an additional system or a helper system. DSS is not intended to replace the expert decision-maker (Power, 2002: 1). Some definitions of decision support systems put forward by experts are explained as follows :

a. According to Man and Watson

Decision Support System is an interactive system, which helps decision-makers through the use of data and decision models to solve problems that are semi-structured and unstructured.

b. According to Maryan Alavi and H. Albert Napier

Decision Support System is a collection of data and information processing procedures oriented to the use of models to produce various answers that can help management in decision making. This system must be simple, easy, and adaptive.

c. According to Litlle

Decision Support System is a computer-based information system that produces a variety of alternative decisions to assist management in handling various structured or unstructured problems using data and models.

d. According to Raymond McLeod, Jr

Decision Support System is a system of producing specific information aimed at solving a particular problem that must be solved by managers at various levels.

From various definitions of The Decision Support System above, it can be concluded that The Decision Support System is a computer-based system that can help decision maker to solve certain problems by utilizing certain data and models.

\subsection{Student Achievement Selection}

In Permendiknas Number 39 The Year 2008 concerning Student Development in Article 3 paragraph 2, namely regarding student coaching material including:

a. Faith and devotion to God Almighty;

b. The Noble character;

c. Superior personality, nationality insight, and national defense;

d. Academic achievement, art, and sports according to their talents and interests;

e. Democracy, human rights, political education, the environment, social sensitivity and tolerance in the context of a plural society;

f. Creativity, skills, and entrepreneurship;

g. Physical, health, and nutrition quality based on diversified nutrition sources;

h. Literature and culture;

i. Information and communication technology;

j. Communication in English;

Achievement students are students who not only excel in academic achievement but must excel in some of the student coaching material listed in Permendikbud No. 39/2008. The purpose of the selection of high achieving students is: 
a. Motivate students in developing their interests and talents to gain achievements in academic and nonacademic fields;

b. Give awards for students who excel;

c. Give motivation to vocational students to keep trying to always excel and get ahead.

\subsection{Simple Multi Attribute Rating Technique (SMART) Method}

SMART (Simple Multi Attribute Rating Technique) is a multi-attribute decision-making method developed by Edward in 1977. This multi-attribute decision-making technique is used to support decision-makers in choosing between several alternatives. Each decision-maker must choose an alternative by the objectives that have been formulated.

Each alternative consists of a set of attributes and each attribute has values. This value is averaged on a certain scale. Each attribute has a weight that illustrates how important compared to other attributes. This weighting and ranking are used to assess each alternative to obtain the best alternative.

The weighting on the SMART (Simple Multi Attribute Rating Technique) uses a scale between 0 to 1 , making it easier to calculate and compare values for each alternative. The models used in the SMART (Simple Multi Attribute Rating Technique) are:

$$
u\left(a_{i}\right)=\sum_{j=1}^{m} w_{j} u_{i}\left(a_{i}\right), \quad i=1,2, \ldots, m
$$

Information :

$w_{i}=$ weighting value of the $\mathrm{jth}$ and $\mathrm{k}$ criteria

$u\left(c_{i}\right)=$ i-criterion utility value for i-criterion

Decision selection is identifying which of the $\mathrm{n}$ alternatives has the greatest function value. The following is a technique for completing the SMART method:

a. Step $1 \quad$ : determine the number of criteria

b. Step 2 : system by default gives a scale of 0-100 based on the priority that has been inputted and then normalized.

$$
\text { Normalisasi }=\frac{w_{j}}{\sum w_{j}}
$$

Information :

$w_{i}=$ Weight of a criterion

c. Step 3: provide criteria values for each alternative.

d. Step 4: calculate the utility value for each criterion.

$$
u_{i}\left(a_{i}\right)=100 \frac{\left(C_{\max }-C_{\text {out } i}\right)}{\left(C_{\max }-C_{\min }\right)} \%
$$

Information :

$$
\begin{array}{ll}
u_{i}\left(a_{i}\right) & : \text { i-th criteria utility value for i-alternative } \\
C_{\text {max }} & : \text { maximum criterion value } \\
C_{\text {min }} & : \text { minimal criterion value } \\
\text { C_(out i) } & : \text { i-th criteria value } \\
\text { e. Step 5: calculate the final value of each. }
\end{array}
$$




\section{Research Method}

This research method is designed to be used as a frame of reference and guide the stages of research. With this research method, it is expected that the research process will be conducted in a directed and systematic manner. This research aims to build a system from scratch. For that reason, this research uses the waterfall software development method, which illustrates a systematic and sequential approach to software development, starting with the specification of user needs and then continuing through the stages of Analisys Of Needs, System Design, System Customization, System Testing, and System Implementation. The stages in developing the application system for selection of achieving student can be seen in the flowchart below.

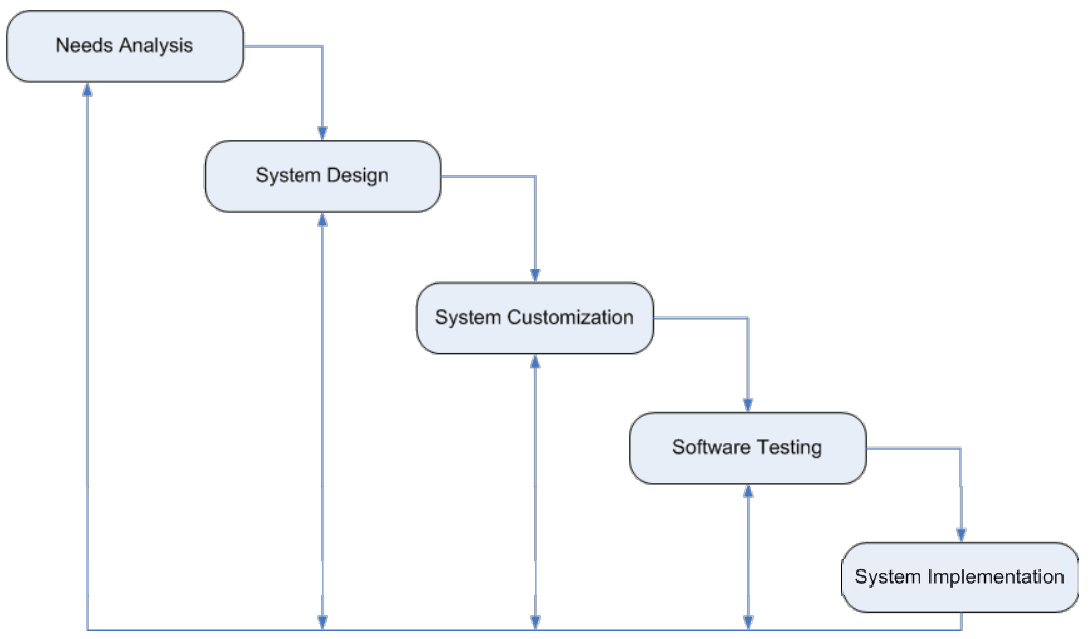

Figure 1. Waterfall Model

\section{Results And Outcomes Achieved}

4.1. Analysis of Needs

4.1.1 Analysis of Input Needs

a. At this stage the user and the developer (researcher) together define the format of the software as a whole, identify all the requirements for the features, and outline of the system to be made.

b. Students who will be interviewed to identify needs are the teacher who is appointed as the selection team for high achieving students in SMA Negeri 1 Sumberpucung.

Table 1. Tabulation of User Needs Design

\begin{tabular}{|c|c|l|}
\hline No. & \multicolumn{1}{|c|}{ Part } & \multicolumn{1}{c|}{ Feature Requirement } \\
\hline & & $>$ Add Prospective Students with \\
& & Achievement / Alternative \\
& & $>$ Add Criteria \\
1 & Admin / Teacher / School Operator & $>$ Input Test Results / Alternative \\
& & Values \\
& & $>$ The count \\
& & $>$ Change Password \\
& $>$ Exit \\
\hline
\end{tabular}

The Criterion that has been determined in the selection of high achieving students are as follows:

a. Criteria for Reporting Semester $1-3(\mathrm{C} 01)$, the report card grades taken are the only semester $1-3$ report cards because participants who are allowed to participate are participants with grade XI only, and the selection time is held during class XI of the 2nd semester, done by finding the average value, which is by the formula: 


$$
N R=\begin{gathered}
R S 1+R S 2+R S 3 \\
3
\end{gathered}
$$

Information :

NR : Report Card Value

RS1: The average value of semester 1 report cards

RS2: The average score of semester 2 report cards

RS3: The average semester report card grade 3

b. Attitude Criteria (C02), Attitude assessment is based on the number of violations or violation points obtained in each student's code of conduct, with the division of grades as follows:

Table 2. Attitude Criteria Assessment Table

\begin{tabular}{|c|c|c|}
\hline No & Big Point Violation & Score \\
\hline 1 & $0-20$ & 100 \\
\hline 2 & $21-40$ & 90 \\
\hline 3 & $41-60$ & 80 \\
\hline 4 & $61-80$ & 70 \\
\hline 5 & $81-100$ & 60 \\
\hline 6 & $101-120$ & 50 \\
\hline 7 & $121-140$ & 40 \\
\hline 8 & $141-160$ & 30 \\
\hline 9 & $161-180$ & 20 \\
\hline 10 & $181-200$ & 10 \\
\hline
\end{tabular}

c. Non-Academic Achievement Criteria (C03), the evaluation of these criterion are based on the nonacademic championships that have been achieved, namely a maximum of 4 races since the range in high school with a minimum grade of 0 and a maximum score of 100, with details as follows:

Table 3. Non-Academic Achievement Criteria Assessment Table

\begin{tabular}{|c|c|c|c|}
\hline No & Championship level & Champion & Score \\
\hline 1 & International & 1 & 60 \\
\hline 2 & International & 2 & 50 \\
\hline 3 & International & 3 & 40 \\
\hline 4 & National & 1 & 50 \\
\hline 5 & National & 2 & 40 \\
\hline 6 & National & 3 & 30 \\
\hline 7 & The province & 1 & 40 \\
\hline 8 & The province & 2 & 30 \\
\hline 9 & The province & 3 & 20 \\
\hline 10 & districts & 1 & 30 \\
\hline 11 & districts & 3 & 20 \\
\hline 12 & districts & & 10 \\
\hline
\end{tabular}

d. Criteria for Participation in Organizations (C04). Evaluation of Organizational Criteria is assessed by position that have been occupied by an organization, a maximum of 3 organizations that have been or are currently being followed in school, and the assessment uses a scale of 0 to 100. The following are assessment of organizational criteria: 
Table 4. Organizational Criteria Assessment Table

\begin{tabular}{|c|c|c|}
\hline No & Position & Score \\
\hline 1 & Chairman & 55 \\
\hline 2 & Secretary & 45 \\
\hline 3 & Treasurer & 35 \\
\hline 4 & Section Chief & 25 \\
\hline 5 & Member & 10 \\
\hline
\end{tabular}

e. Written Test Criteria (C05), is a selection process that hones their abilities in the fields of numerical, literacy, and figural. Assessment in these criterion uses a scale of 0-100. In the criteria that have been determined in the SMART method it is necessary to determine the weight level of each criteria, as below:

Table 5. Criteria Table With Weight

\begin{tabular}{|c|l|c|}
\hline No & \multicolumn{1}{|c|}{ Position } & Weight \\
\hline 1 & Report Card Value Criteria (C01) & 90 \\
\hline 2 & Attitude Criteria (C02) & 75 \\
\hline 3 & $\begin{array}{l}\text { Non-Academic Achievement } \\
\text { Criteria (C03) }\end{array}$ & 85 \\
\hline 4 & $\begin{array}{l}\text { Organizational Participation } \\
\text { Criteria (C04) }\end{array}$ & 55 \\
\hline 5 & Writing Test Criteria (C05) & 100 \\
\hline \multicolumn{2}{|l}{ Weight Amount } \\
\hline
\end{tabular}

\subsubsection{Analysis of Output Needs}

The resulting data output is an alternative that has the highest value compared to other value alternatives. Outputs are taken from the highest alternative order to the lowest alternative. The result will be displayed by the program derived from the value of each criterion because each criterion has a different value. The intended alternative is the participant selection candidates for outstanding students.

\subsection{System Design}

The design is the stage of preparation of the most optimal process, data, process flow, and data relationship to run the application process and meet user needs by the results of the needs analysis. Documentation that resulted from this system design stage include:

\subsubsection{System Block Diagram}

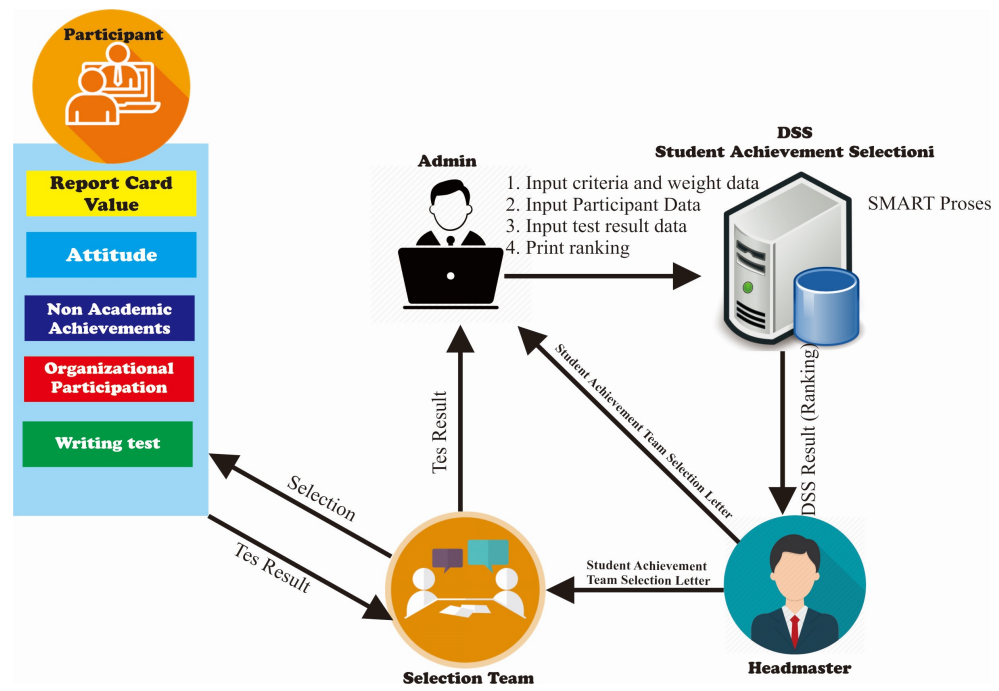

Figure 2. System Block Diagram 


\subsubsection{Context Diagram}

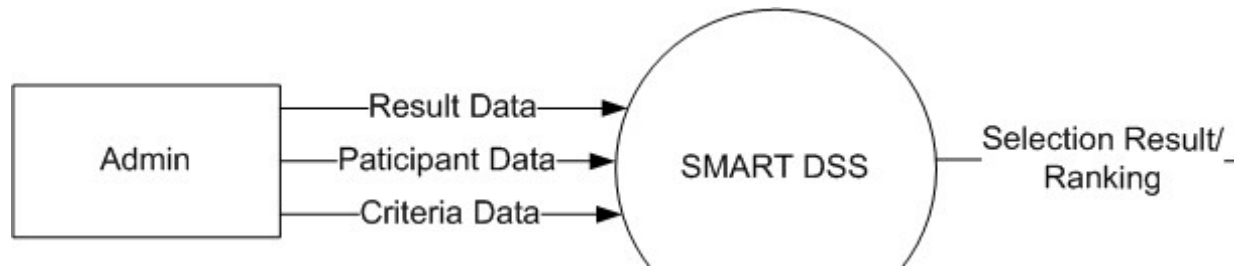

Figure 3. Context Diagram

4.2.3 Data Flow Diagrams (DFD)

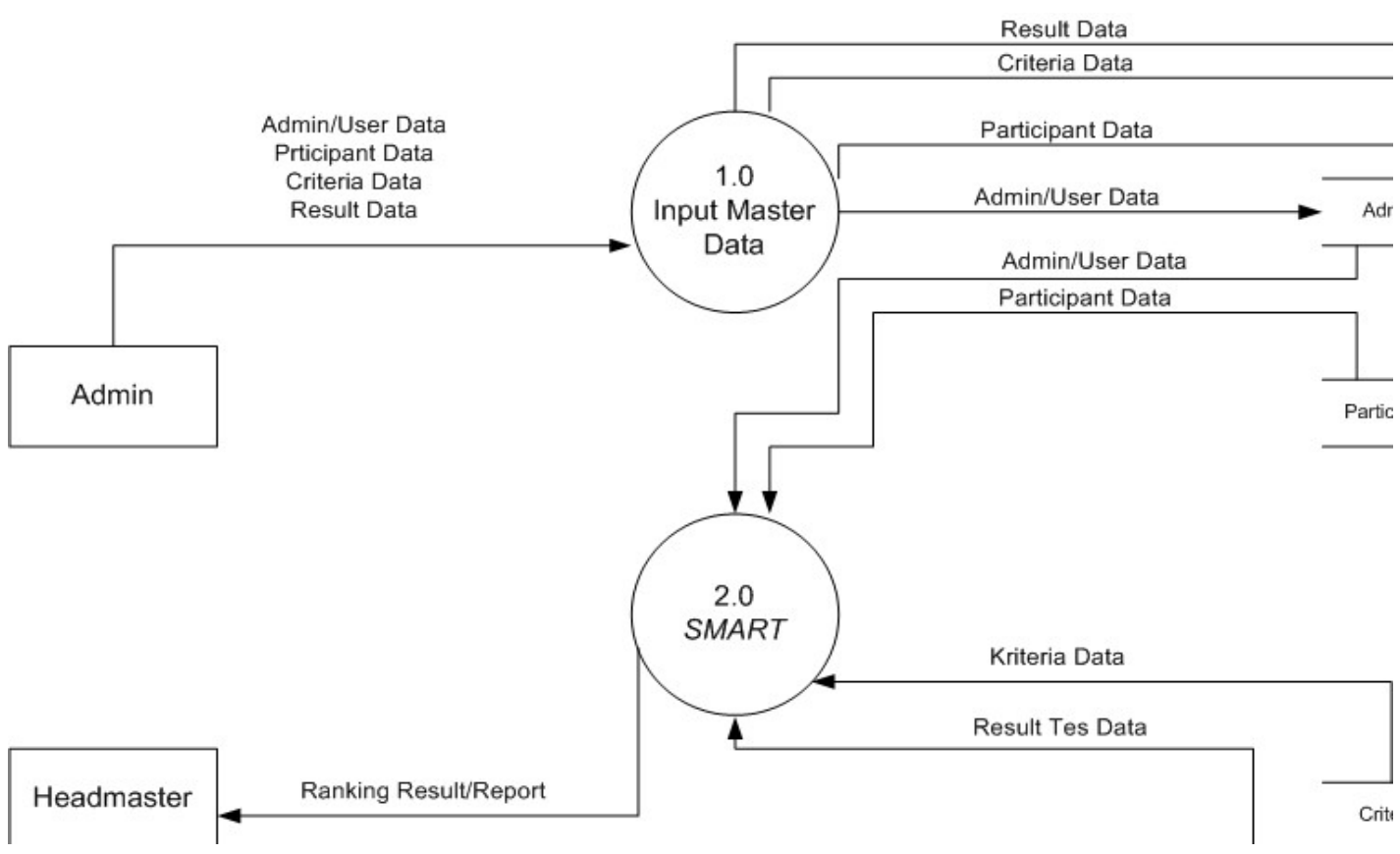

Figure 4. Data Flow Diagrams (DFD)

\subsubsection{Database Design}

a. Admin Table (tb_admin)

Table 6. Admin Table Structure

\begin{tabular}{|c|l|c|c|c|}
\hline No & \multicolumn{1}{|c|}{ Field } & Data Type & Null & Information \\
\hline 1 & user & Varchar (16) & No & \\
\hline 2 & pass & Varchar (16) & Yes & \\
\hline 3 & level & Varchar (16) & Yes & \\
\hline
\end{tabular}


b. Alternative Table (tb_alternatif)

Table 7. Alternative Table Structures

\begin{tabular}{|c|l|c|c|c|}
\hline No & \multicolumn{1}{|c|}{ Field } & Data Type & Null & Information \\
\hline 1 & alternative_code & Varchar (16) & No & \\
\hline 2 & alternative_name & Varchar (255) & Yes & \\
\hline 3 & total & Double & Yes & \\
\hline 4 & rank & Int (11) & Yes & \\
\hline
\end{tabular}

c. Criteria Table (tb criteria)

Table 8. Structure of the Criteria Table

\begin{tabular}{|c|l|c|c|c|}
\hline No & \multicolumn{1}{|c|}{ Field } & Data Type & Null & Information \\
\hline 1 & criteria_code & Varchar (16) & No & \\
\hline 2 & criteria_name & Varchar (255) & Yes & \\
\hline 3 & weight & Double & Yes & \\
\hline
\end{tabular}

d. Results Table (tb_rel_alternative)

Table 9. Structure of Profile Table

\begin{tabular}{|c|l|c|c|c|}
\hline No & \multicolumn{1}{|c|}{ Field } & Data Type & Null & Information \\
\hline 1 & ID & Int (11) & No & Auto Increment \\
\hline 2 & alternative_code & Varchar (16) & No & \\
\hline 3 & criteria_code & Varchar (16) & No & \\
\hline 4 & score & Double & No & \\
\hline
\end{tabular}

\subsection{System Customization}

Customizing the program code is the stage of translating the system design into the program by adjusting the menus or features of the decision support system. At this stage, a menu or feature on the decision support system will be generated that will suit the user's needs.

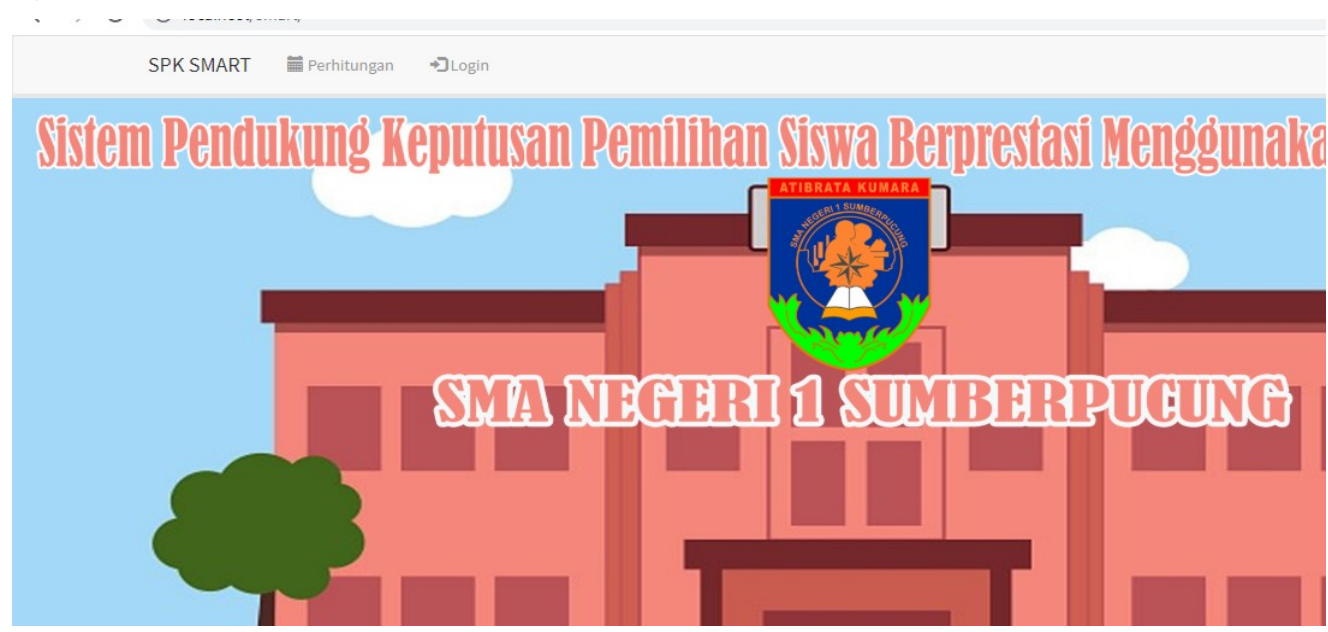

Figure 5. Start Page 


\begin{tabular}{|c|c|c|}
\hline SPK SMART & ㄹ. Perhitungan & $\rightarrow$ Login \\
\hline \multicolumn{3}{|l|}{ Login } \\
\hline \multicolumn{3}{|l|}{ Username } \\
\hline \multicolumn{3}{|l|}{ Username } \\
\hline \multicolumn{3}{|l|}{ Password } \\
\hline \multicolumn{3}{|c|}{ Password } \\
\hline \multicolumn{3}{|c|}{ User: admin, Pass: admin } \\
\hline \multicolumn{3}{|l|}{ JMasuK } \\
\hline
\end{tabular}

Figure 6. Log In Page

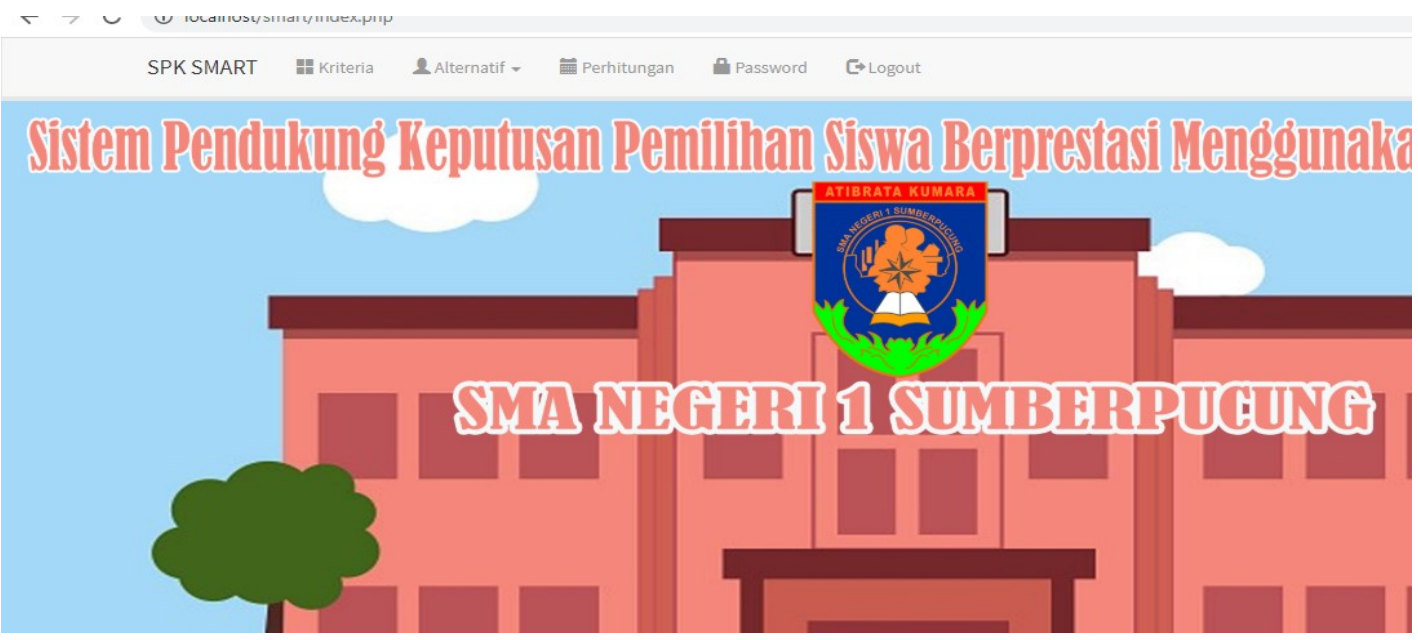

Figure 7. Main Page / Home

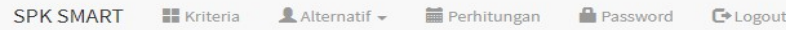

\section{Kriteria}

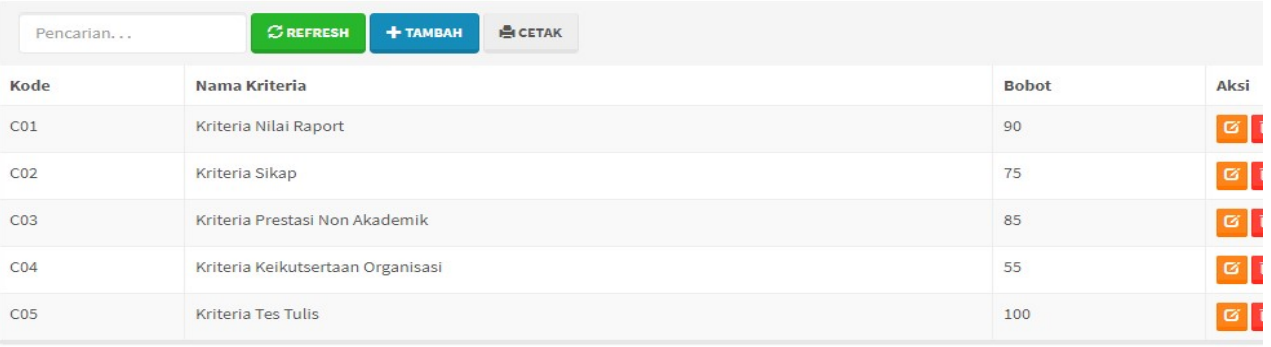

Figure 8. Criteria and Weight Data Entry Page 


\begin{tabular}{|c|c|c|c|c|}
\hline SPK SMART & \#I Kriteria & 2Alternatif & E Perhitungan & EF Logout \\
\hline \multicolumn{5}{|c|}{ Alternatif } \\
\hline \multicolumn{2}{|c|}{ Pencarian... } & ఇREFRESH & + ТАMван & \\
\hline No & Kode & & Nama Alternatif & Aksi \\
\hline 1 & A01 & & AFIF ARAHMAN & G \\
\hline 2 & A02 & & AMANDA CALLISTA AGUSTIN & 줌 \\
\hline 3 & ${ }_{\mathrm{A} 03}$ & & MUCHAMAD BAGUS TRIYADI & 줌 \\
\hline 4 & A04 & & RAMADHANI HUDAN AQROBI & 둘 \\
\hline 5 & A05 & & NOVITA ARDIANA & 둥 \\
\hline
\end{tabular}

Figure 9. Alternative Data Entry / Participant Pages
SPK SMART
: Kriteria
2Alternatif -
풀 Perhitungan
A Password
C- Logout

\section{Nilai Bobot Alternatif}

\begin{tabular}{|c|c|c|c|c|c|c|c|}
\hline & ¿ REFRESH & $\because$ ЄЕTAK & & & & & \\
\hline Kode & Nama Alternatif & & c01 & $\mathrm{c02}$ & $\mathrm{c03}$ & C04 & c05 \\
\hline A01 & AFIF ARAHMAN & & 75 & 100 & 80 & 90 & 70 \\
\hline A02 & AMANDA CALLISTA AGUSTIN & & 90 & 100 & 60 & 70 & 70 \\
\hline A03 & MUCHAMAD BAGUS TRIYADI & & 80 & 90 & 85 & 60 & 70 \\
\hline A04 & RAMADHANI HUDAN AQROBI & & 70 & 80 & 50 & 40 & 80 \\
\hline A05 & NOVITA ARDIANA & & 80 & 70 & 80 & 90 & 70 \\
\hline
\end{tabular}

Figure 10. Alternative Weight Value Entry Page / Participant Test Results

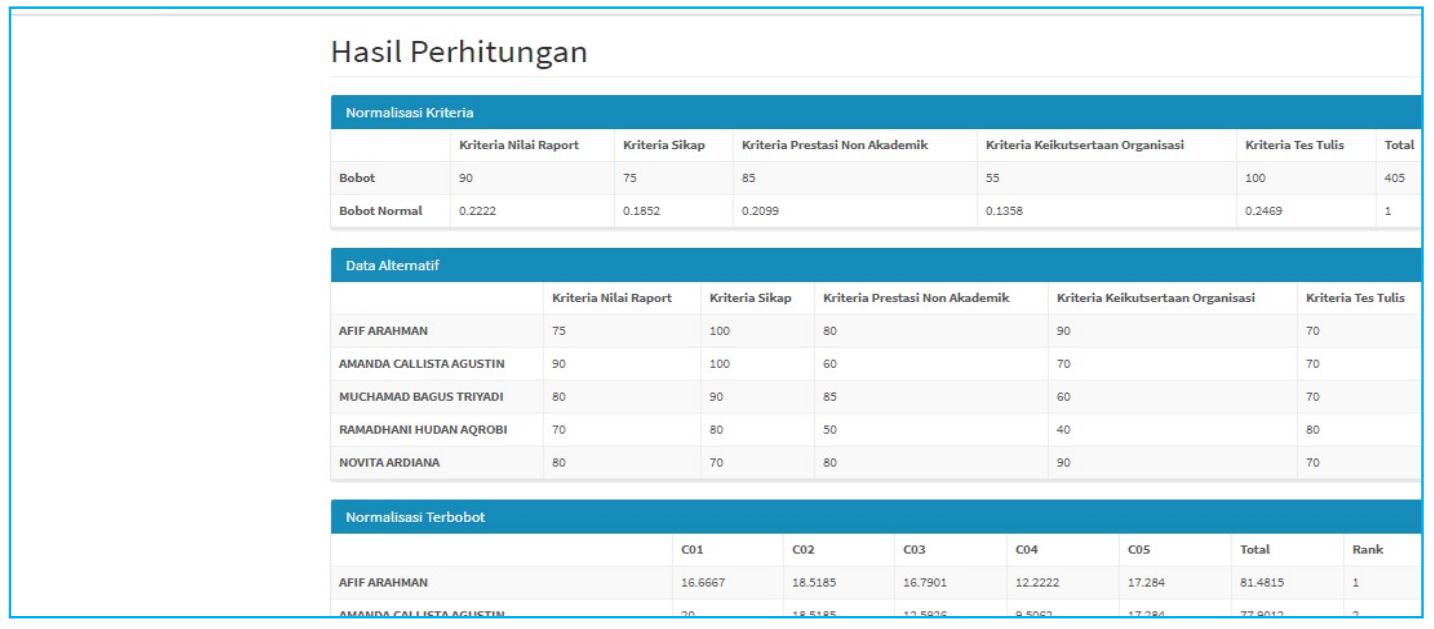

Figure 11. Calculation Results Page 
4.4 Software Testing

At this stage, all input and output processes are tested with a black box method so that the possibility of errors and bugs can be immediately identified and improvements made in writing the program code. Testing the program on the localhost using Xampp.

\subsection{System Implementation}

After the user states that the system is under expectations and needs, then the decision support system is ready to be applied.

\section{Conclusion}

The existence of a decision support system for high achieving students in SMA Negeri 1 Sumberpucung, the decision taken by the School Principal in determining high achieving students is no longer subjective and the result of the decision taken is the best decision objectively useful for its sustainability in the selection of outstanding students at the district level.

This research was funded by a novice lecturer research scheme

\section{References}

Kusrini. "Concepts and Applications of Decision Support Systems”, Yogyakarta: CV Andi Offset.2007

Regulation of the Minister of Education and Culture of the Republic of Indonesia Number 84 of 2013 concerning the appointment of non-civil servant permanent lecturers in state universities and permanent lecturers in private tertiary institutions

Power, Daniel J. "Decision Support System: Concepts and Resources for Managers", Greenwood Publishing's Quorum Books division. USA.2002.

Powers, "DMW Evaluation: From Precision, Recall and Features to Roc, Informedness, Markedness \& Correlation", Journal of Machine Learning Technologies. ISSN: 2229-3981 \& ISSN: 2229-399X, Volume 2, Issue 1, 2011, pp- 37-63.2011.

Farid Wahyudi, S.Kom., M.M is a Lecturer on Information System Study Program, Faculty of Science and Technology, Raden Rahmat Islamic University of Malang, Indonesia. His research interests are in Management Information Systems, Decision Support System, Artificial Intelligence, and Web Programming

Listanto Tri Utomo, S.Kom., M.M is a Lecturer on Informatics Engineering Study Program, Faculty of Science and Technology, Raden Rahmat Islamic University of Malang, Indonesia. His research interests are in Management Information Systems and Android Programming. 